\title{
A Synthesis of Optically Active Key Intermediate for the Synthesis of Optically Active Thromboxanes
}

\author{
Hiroshi OHRu and Sakae Emoto \\ The Institute of Physical and Chemical Research, Wako-shi, \\ Saitama 35I, Japan \\ Received May 2, 1977
}

\begin{abstract}
An optically active key intermediate, methyl 2, 4-dideoxy-4-C-carboxymethylene- $\alpha$-Dribo-hexopyranoside $2^{\prime} \rightarrow 3$ lactone (XII), for the syntheses of optically active Thromboxanes was prepared from $\mathrm{D}$-glucose.
\end{abstract}

Recently, Hamberg and Samuelsson found a significant new branch in the arachidonic acid metabolism. ${ }^{1}$ The endoperoxide $\left(\mathrm{PGG}_{2}\right)$ which had previously been known to give the prostagrandins (e.g. $\mathrm{PGE}_{2}$ and $\mathrm{PGF}_{2}$ ) was found to give a new type of short lived, but extremely biologically active substance called Thromboxane $\left.\mathrm{A}_{2}\left(\mathrm{TXA}_{2}\right)\right)^{1,2)}$ This substance, of which half life in aqueous solution is 30 seconds, has a profound effect on certain smooth muscles and cells and appears to be an important early factors in Thrombosis. Thromboxane $\mathrm{A}_{2}$ is rapidly converted to Thromboxane $\mathrm{B}_{2}\left(\mathrm{TXB}_{2}\right)$, of which little has been known regarding biological activity.

As a part of our studies on the stereoselective syntheses of biologically active compounds in optically active forms by use of asymmetric carbons of carbohydrates, ${ }^{3}$, we have planned the synthesis of optically active Thromboxanes from D-glucose. Short after our project was started, two syntheses of

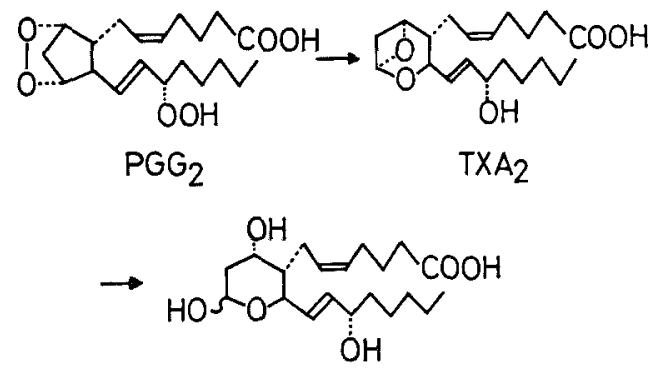

$\mathrm{TXB}_{2}$

FIG. 1.
Thromboxane $\mathbf{B}_{2}$ starting from the "Corey lactones" via the same key intermediate "lactone alcohol" have been reported by the Upjohn Company groups., ${ }^{4}$ ) In this paper, we would like to describe the synthesis of the key intermediate "lactone alcohol" in an optically active form from D-glucose. ${ }^{6)}$

D-Glucose was converted to methyl 2,3anhydro-4, 6-O-benzylidene- $\alpha$-D-allopyranoside (I) by the well established method. ${ }^{7}$ The reduction of $\mathbf{I}$ with lithium aluminum hydride was carried out in a slightly modified method from the original method. ${ }^{8)}$ The change of the solvent from ether to tetrahydrofurane resulted in the raise of the yield of the desired 2-deoxy sugar (II) from $86 \%$ to almost quantitative. Treatment of $\mathbf{I}$ with benzyl chloride in the presence of powdered potassium hydroxide at $100^{\circ} \mathrm{C}$ for $4 \mathrm{hr}$ gave a crystalline benzyl ether III, mp $95 \sim 96^{\circ} \mathrm{C}$, in good yield. In order to assign the chemical shift of $\mathrm{H}-3$ of $\mathbf{I I}$ in the NMR spectrum, two other derivatives of $\mathbf{I}, 3-\mathrm{O}$-benzoate (IIIb) and 3-O-p-toluenesulfonate (III), were prepared. The signals of $\mathrm{H}-3$ of these compounds appeared as very similar multiplets but at very different chemical shifts. Therefore, the chemical shifts ( $\delta$ values) of these three protons of III, IIIb and WIc were easily assigned as $3.96,5.54$ and 4.89 , respectively.

Treatment of III with $85 \%$ acetic acid overnight at room temperature gave a syrupy methyl 3-O-benzyl-2-deoxy - $\alpha$-D - ribo-hexopyranoside (IV) in $73 \%$ yield. Partial benzoy- 
lation of IV with 1.2 equivalent of benzoyl chloride in a mixture of pyridine and dichloromethane $(1: 1, \mathrm{v} / \mathrm{v})$ for $3 \mathrm{hr}$ at $0^{\circ} \mathrm{C}$ and then overnight at room temperature gave two major products. They were purified by column chromatography on silicic acid with a mixture of benzene and ethyl acetate $(10: 1, \mathrm{v} / \mathrm{v})$ as an eluent. The IR spectrum of the faster eluted compounds $(12 \%)$ showed the absence of hydroxy group and its ${ }^{1} \mathrm{H}$ NMR spectrum showed the presence of two benzoyl groups. Therefore, this compound was assigned as methyl 3-O-benzyl-4,6-di-O-benzoyl-2-deoxy- $\alpha$ D-ribo-hexopyranoside (V). The IR spectrum of the slower eluted compound showed the presence of both hydroxy and ester groups. The signal of the hydroxy group in its ${ }^{1} \mathrm{H}$ NMR spectrum appeared as a doublet indicating a secondary alcohol. Therefore, this compound was assigned as methyl 3-O-benzyl-6-O-benzoyl-2-deoxy- $\alpha$-D-ribo-hexopyranoside (VI).

The oxidation of VI with ruthenium dioxide and sodium metaperiodate in a mixture of carbontetrachloride and water gave the ketone VII, which was treated directly with the ylide prepared from trimethylphosphonoacetate and $n$-butyl lithium in tetrahydrofurane at $-30^{\circ} \mathrm{C}$ to give a $1: 1$ mixture of $\alpha, \beta$-unsaturated esters VIIIa and VIIIb in a total yield of $60 \%$. They were separated by a column chromatography on silicic acid with a mixture of benzene and ethyl acetate $(10: 1, \mathrm{v} / \mathrm{v})$ as an eluent. The ${ }^{1} \mathrm{H}$ NMR spectra of VIIIa and VIIIb were shown in Figs. 2 and 3, respectively. As can be seen in Fig. 2, the benzyl protons of the faster eluted VIIIa appeared as AB type pattern. On the other hand, the benzyl protons of the slower eluted VIIb appeared almost equivalent. These facts indicated that the benzyl group of VIIIa would be in the nearer position to the carbomethoxy group than that of VIUb. Therefore, the compounds VIII a and VIIIb were assigned as $\mathbf{E}$ and $\mathbf{Z}$ configuration respectively as shown in Fig. 4.

The catalytic reduction of VIIIa over $10 \%$ $\mathrm{Pd}-\mathrm{C}$ in ethanol gave a main product $\mathbf{I X}$ and a very small amount of another product $\mathbf{X}$. The main product $\mathbf{I X}$ changed slowly to $\mathbf{X}$ on standing in solution. Several attempts to isolate IX in an analytically pure form were not successful because $\mathbf{I X}$ changed to $\mathbf{X}$ during purification process and was always contaminated with $\mathbf{X}$. Therefore, the crude IX was treated directly with silicic acid in toluene at reflux to give the crystalline $\mathbf{X}, \mathrm{mp} 102 \sim$ $103^{\circ} \mathrm{C}$, in $83 \%$ yield. The IR spectrum of $\mathbf{X}$ showed the presence of both ester $\left(1710 \mathrm{~cm}^{-1}\right)$ and lactone $\left(1760 \mathrm{~cm}^{-1}\right)$ groups. The ${ }^{1} \mathrm{H}$ NMR spectrum of $\mathbf{X}$ showed the presence of benzoyl group and the absence of benzyl group. Therefore, compound $\mathbf{X}$ was assigned as methyl 6-O-benzoyl-2,4-dideoxy-4-C-carboxymethylene- $\alpha$-D-ribo-hexopyranoside $2^{\prime} \rightarrow 3$ lactone and compound IX as methyl 6-O-benzoyl2, 4-dideoxy-4- $C$-carbomethoxymethylene- $\alpha$-Dribo-hexopyranoside.

On the other hand, the catalytic reduction of VIIIb under similar conditions gave a $1: 1$ mixture of IX and a new hydroxy ester XI, $\mathrm{mp} 77 \sim 78^{\circ} \mathrm{C}$. The new hydroxy ester XI could not be lactonized under similar conditions as that lactonized IX. This fact indicated that the ester and the hydroxy groups should be in the trans relation on the pyranose ring. Therefore, the new hydroxy ester was assigned as methyl 6-O-benzyoyl-2,4-dideoxy-4-C-carbomethoxymethylene- $\alpha-\mathrm{D}-x y$ lo - hexopyranoside (XI).

Treatment of $\mathbf{X}$ with $0.05 \mathrm{~N}$ sodium methoxide in methanol overnight at room temperature gave the syrupy lactone alcohol, methyl 2,4-dideoxy-4-C -carboxymethylene- $\alpha$ - D -ribohexopyranoside (XII), $[\alpha]_{\mathrm{D}}^{20}+100^{\circ} \quad(c=0.09$, $\mathrm{CHCl}_{3}$ ), in $83 \%$ yield.

Treatment of XII with $p$-phenylbenzoyl chloride in pyridine gave the corresponding p-phenylbenzoate XIII, mp $149 \sim 150^{\circ} \mathrm{C}$ ( $c f$. lit. $\left.{ }^{4,9)} \mathrm{mp} 149.5 \sim 150^{\circ} \mathrm{C}\right),[\alpha]_{\mathrm{D}}^{20}+48.6^{\circ}(c=$ $0.18, \mathrm{CHCl}_{3}$ ).

The syntheses of optically active Thromboxanes from XI are now in progress in our laboratory.

\section{EXPERIMENTAL}

All melting points were not corrected. Optical rotations were measured with a Perkin-Elmer 141 
polarimeter. ${ }^{1} \mathrm{H}$ NMR spectra were obtained using a Varian HA-100 spectrometer. Column chromatography was performed using 70-230 mesh Merck silica gel. Thin-layer chromatography was done using silica gel GF 254.

\section{Methyl 4,6-O-benzylidene-2-deoxy- $\alpha$-D-ribo-hexopyra- noside (II)}

To a suspension of $\mathbf{I}(79 \mathrm{~g})$ in dry tetrahydrofurane $(1000 \mathrm{ml})$ was added lithium aluminum hydride $(6 \mathrm{~g})$ with stirring at room temperature. The temperature of the reaction mixture was raised to about $50 \sim 60^{\circ} \mathrm{C}$ and the starting material went into solution completely. After the reaction mixture was stirred for $4 \mathrm{hr}$ at the temperature, saturated aqueous sodium tartarate $(200 \mathrm{ml})$ was added to it. The aqueous layer was separated and was extracted five times with ether $(100 \mathrm{ml})$. The tetrahydrofurane layer and the ether extract were combined and evaporated under reduced pressure to give a crystalline mass. It was dissolved in dichloromethane $(1000 \mathrm{ml})$ and the solution was washed with saturated aqueous ammonium chloride solution (200 $\mathrm{ml}$ ). The organic layer was dried over $\mathrm{Na}_{2} \mathrm{SO}_{4}$ and evaporated in vacuo to give the crystalline II ( $80 \mathrm{~g}$, quantitative). It was pure enough to be used for the next step.

\section{Methyl 3-O-benzyl-4,6-O-benzylidene-2-deoxy-a-D-ribo-} hexopyranoside (III)

A mixture of II $(27 \mathrm{~g})$ and powdered potassium hydroxide $(100 \mathrm{~g})$ in benzyl chloride $(300 \mathrm{ml})$ was stirred vigorously at $100^{\circ} \mathrm{C}$ for $3 \mathrm{hr}$. After the reaction mixture was cooled, water $(200 \mathrm{ml})$ was added to it. It was extracted five times with ether $(100 \mathrm{ml})$. The extracts were combined and washed with saturated ammonium chloride solution $(300 \mathrm{ml})$. The ether and the excess benzyl chloride were evaporated under reduced pressure to give a crystalline mass. It was recrystallized from cyclohexane to give III $(35 \mathrm{~g}, 95 \%)$, mp $95 \sim 96^{\circ} \mathrm{C},[\alpha]_{\mathrm{D}}^{16}+59.9^{\circ}\left(c=1.0, \mathrm{CHCl}_{3}\right)$. Anal. Found: C, 71.00; H. 6.75. Calcd. for $\mathrm{C}_{21} \mathrm{H}_{24} \mathrm{O}_{5}$ : C, $70.76 ; \mathrm{H}, 6.79 \% . \quad \mathrm{NMR} \delta_{\mathrm{Me}_{4} \mathrm{Si}_{\mathrm{i}}}^{\mathrm{CDCl}_{3}}: 1.76 \sim 2.33(2 \mathrm{H}, \mathrm{m}$, $\left.J_{2,2^{\prime}}=15 \mathrm{~Hz}, \mathrm{H}_{2}, \mathrm{H}_{2^{\prime}}\right), 3.37\left(3 \mathrm{H}, \mathrm{s}, \mathrm{OCH}_{3}\right), 3.50 \sim$ $3.87\left(2 \mathrm{H}, \mathrm{m}, \mathrm{H}_{8}, \mathrm{H}_{\theta^{\prime}}\right), 3.96\left(1 \mathrm{H}, \mathrm{m}, \mathrm{H}_{3}\right), 4.20 \sim 4.63$ $\left(2 \mathrm{H}, \mathrm{m}, \mathrm{H}_{4}, \mathrm{H}_{5}\right), 4.72\left(1 \mathrm{H}, \mathrm{d}, J=4 \mathrm{~Hz}, \mathrm{H}_{1}\right), 4.80(2 \mathrm{H}$, $\mathrm{s}$, benzyl protons), $5.54(1 \mathrm{H}, \mathrm{s}$, benzylidene proton), $7.16 \sim 7.66(10 \mathrm{H}, \mathrm{m}$, aromatic protons).

\section{Methyl 3-O-benzoyl-4,6-O-benzylidene-2-deoxy- $\alpha-D-r i b o-$ hexopyranoside (IIb)}

To a solution of $I I(5.4 \mathrm{~g})$ in pyridine $(50 \mathrm{ml})$ was added benzoyl chloride $(4.0 \mathrm{~g})$ at $0^{\circ} \mathrm{C}$. The mixture was stirred for $2 \mathrm{hr}$ at $0^{\circ} \mathrm{C}$ and then overnight at room temperature. Water $(100 \mathrm{ml})$ was added to the reaction mixture and the mixture was stirred for additional $1 \mathrm{hr}$. It was extracted three times with dichlorome- thane $(50 \mathrm{ml})$. The organic layer was succesively washed with cold $3 \% \mathrm{H}_{2} \mathrm{SO}_{4}(1000 \mathrm{ml})$, water $(50 \mathrm{ml})$, saturated $\mathrm{NaHCO}_{3}(50 \mathrm{ml})$ and then water $(50 \mathrm{ml})$. The dichloromethane solution was dried over $\mathrm{Na}_{2} \mathrm{SO}_{4}$ and evaporated under reduced pressure to give a syrup $(7.5 \mathrm{~g})$. The syrup was purified by column chromatography on silicic acid $(200 \mathrm{~g})$ using a mixture of benzene and ethyl acetate $(30: 1, \mathrm{v} / \mathrm{v})$ as an eluent to give a syrupy IIIb $(7 \mathrm{~g}, 94 \%),[\alpha]_{D}^{21}+179.1^{\circ}\left(c=0.15, \mathrm{CHCl}_{3}\right)$. Anal. Found: $\mathrm{C}, 67.92 ; \mathrm{H}, 5.75$. Calcd. for $\mathrm{C}_{21} \mathrm{H}_{22} \mathrm{O}_{\theta}$ :

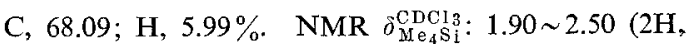
$\left.\mathrm{m}, \mathrm{H}_{2}, \mathrm{H}_{2^{\prime}}\right), 3.35\left(3 \mathrm{H}, \mathrm{s}, \mathrm{OCH}_{3}\right), 3.60 \sim 4.00(2 \mathrm{H}, \mathrm{m}$, $\left.\mathrm{H}_{8}, \mathrm{H}_{8^{\prime}}\right), 4.20 \sim 4.70\left(2 \mathrm{H}, \mathrm{m}, \mathrm{H}_{4}, \mathrm{H}_{5}\right), 4.76(1 \mathrm{H}, \mathrm{d}$, $\left.J=4 \mathrm{~Hz}, \mathrm{H}_{1}\right), 5.54\left(1 \mathrm{H}, \mathrm{m}, \mathrm{H}_{3}\right), 5.60(1 \mathrm{H}, \mathrm{s}$, benzylidene proton).

\section{Methyl 4, 6-O-benzylidene-2-deoxy-3-O-p-toluenesul-}

fonyl- $\alpha$-D-ribo-hexopyranoside (IIIc)

To a solution of II $(5.4 \mathrm{~g})$ in pyridine $(50 \mathrm{ml})$ was added $p$-toluensulfonyl chloride $(5.0 \mathrm{~g})$ at $0^{\circ} \mathrm{C}$. The reaction mixture was stirred overnight at room temperature. The reaction mixture was diluted with dichloromethane $(200 \mathrm{ml})$. The dichloromethane solution was successively washed with cold $3 \% \mathbf{H}_{2} \mathrm{SO}_{4}(1000 \mathrm{ml})$, water $(50 \mathrm{ml})$, saturated $\mathrm{NaHCO}_{3}(50 \mathrm{ml})$ and again with water $(50 \mathrm{ml})$. The organic layer was dried over $\mathrm{Na}_{2} \mathrm{SO}_{4}$ and evaporated under reduced pressure to give a crystalline mass $(8 \mathrm{~g})$. It was recrystallized from 2-propanol to give a crystalline IIIc $(7.5 \mathrm{~g}, 90 \%) \mathrm{mp}$ $119 \sim 120^{\circ} \mathrm{C}, \quad[\alpha]_{\mathrm{D}}^{21}+72.0^{\circ} \quad\left(c=0.8, \quad \mathrm{CHCl}_{3}\right) . \quad$ Anal. Found: $\mathrm{C}, 59.60 ; \mathrm{H}, 5.57 ; \mathrm{S}, 7.58$. Calcd. for $\mathrm{C}_{21} \mathrm{H}_{24}$ $\mathrm{SO}_{7}: \mathrm{C}, 59.99 ; \mathrm{H}, 5.75 ; \mathrm{S}, 7.62 \% . \mathrm{NMR} \delta_{\mathrm{Me}_{4} \mathrm{Si}_{1}}^{\mathrm{CDCl}_{3}}$ $1.80 \sim 2.60\left(2 \mathrm{H}, \mathrm{m}, \mathrm{H}_{2}, \mathrm{H}_{2^{\prime}}\right), 2.32\left(3 \mathrm{H}, \mathrm{s}, \mathrm{CH}_{3}-\mathrm{Ph}\right)$, $3.36\left(3 \mathrm{H}, \mathrm{s}, \mathrm{OCH}_{3}\right), 3.50 \sim 3.80\left(2 \mathrm{H}, \mathrm{m}, \mathrm{H}_{6}, \mathrm{H}_{B^{\prime}}\right), 4.10 \sim$ $4.44\left(2 \mathrm{H}, \mathrm{m}, \mathrm{H}_{4}, \mathrm{H}_{5}\right), 4.74\left(1 \mathrm{H}_{4} \mathrm{~d}, J=4 \mathrm{~Hz}, \mathrm{H}_{1}\right), 4.87$ $\left(1 \mathrm{H}, \mathrm{m}, \mathrm{H}_{3}\right), 5.45(1 \mathrm{H}, \mathrm{s}$, benzylidene proton $)$.

\section{Methyl 3-O-benzyl-2-deoxy- $\alpha-D$-ribo-hexopyranoside}

(IV)

A solution of III $(10 \mathrm{~g})$ in $80 \%$ aqueous acetic acid $(100 \mathrm{ml})$ was stirred overnight at room temperature. The solvent was evaporated under reduced pressure below $40^{\circ} \mathrm{C}$ to give a syrup $(10 \mathrm{~g})$. The syrup was purified by a column chromatography on silicic acid (250 g) using a mixture of $\mathrm{CHCl}_{3}$ and $\mathrm{MeOH}$ (20: 1, $\mathrm{v} / \mathrm{v})$ as an eluent. The fractions that contained the compound with $R f=0.2$ (the same solvent system as the eluent) were collected. Evaporation of the solvent gave a syrupy IV $(7.2 \mathrm{~g}, 95 \%),[\alpha]_{\mathrm{D}}^{21}+161.9^{\circ}(c=0.1$, $\mathrm{CHCl}_{3}$ ). Anal. Found: C, 62.37; H, 7.35\%. Calcd. for $\mathrm{C}_{14} \mathrm{H}_{20} \mathrm{O}_{5}: \mathrm{C}, 62.67, \mathrm{H}, 7.51$. NMR $\delta_{\mathrm{Me}_{4} \mathrm{Si}}^{\mathrm{CDCl3}}: 1.52 \sim$ $2.46\left(2 \mathrm{H}, \mathrm{m}, J_{2,2^{\prime}}=15 \mathrm{~Hz}, \mathrm{H}_{2}, \mathrm{H}_{2^{\prime}}\right), 3.34\left(3 \mathrm{H}, \mathrm{s}, \mathrm{OCH}_{3}\right)$, $3.60(1 \mathrm{H}, \mathrm{m}), 3.70 \sim 4.08(4 \mathrm{H}, \mathrm{m}), 4.40$ and $4.80(2 \mathrm{H}$, $2 \mathrm{~d}, J=12 \mathrm{~Hz}$, benzyl protons), $4.80(1 \mathrm{H}, \mathrm{d}, J=4 \mathrm{~Hz}$, $\left.\mathrm{H}_{1}\right), 7.20 \sim 7.46(5 \mathrm{H}, \mathrm{m}$, aromatic protons). 


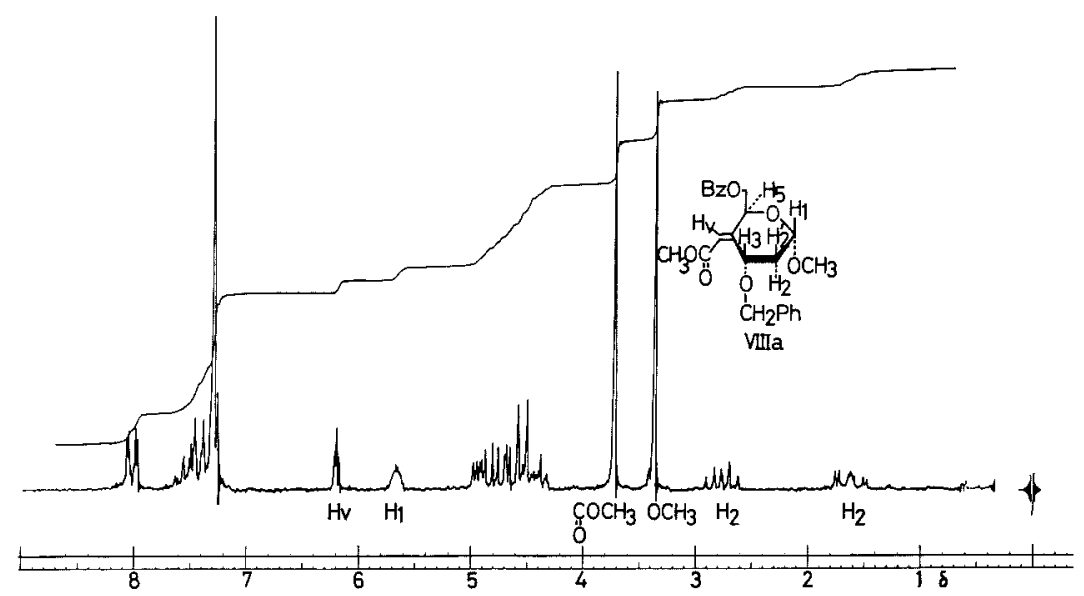

FIG. 2. NMR Spectrum of VIIIa.

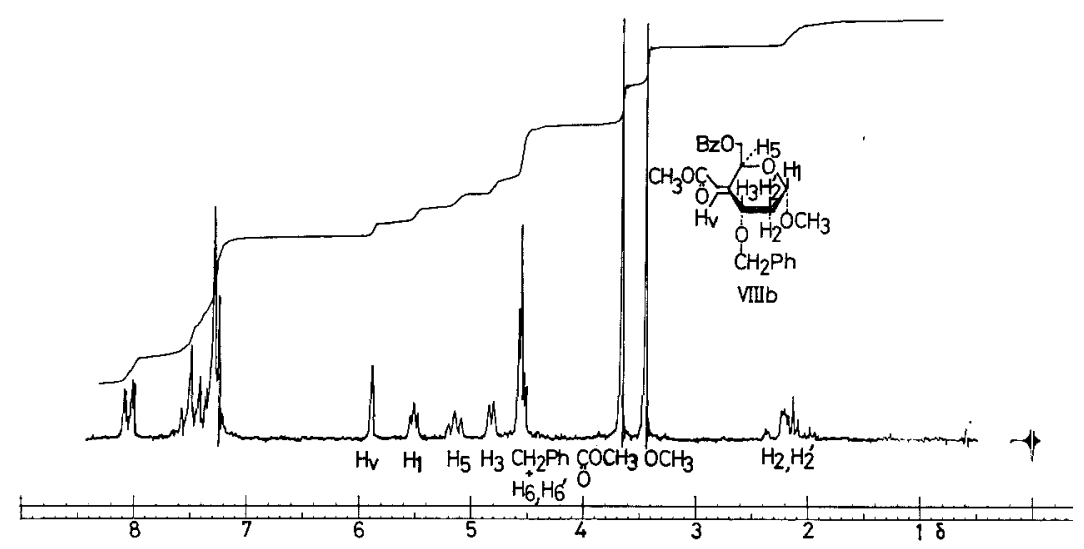

FIG. 3. NMR Spectrum of VIIIb.

Methyl 6-O-benzoyl-3-O-benzyl-2-deoxy-a-D-ribohexopyranoside (VI)

To a solution of IV $(8.0 \mathrm{~g})$ in a mixture of pyridine and dichloromethane $(1: 1, \mathrm{v} / \mathrm{v}, 200 \mathrm{ml})$ was added benzoyl chloride $(5.0 \mathrm{~g})$ under cooling in an ice-water bath. The reaction mixture was stirred for $3 \mathrm{hr}$ at $0^{\circ} \mathrm{C}$ and then overnight at room temperature. The mixture was diluted with dichloromethane $(500 \mathrm{ml})$ and washed succesively with cold $3 \% \mathrm{H}_{2} \mathrm{SO}_{4}(2000 \mathrm{ml})$, saturated $\mathrm{NaHCO}_{3}(100 \mathrm{ml})$ and then water $(100 \mathrm{ml})$. The dichloromethane solution was dried over $\mathrm{Na}_{2} \mathrm{SO}_{4}$ and evaporated under reduced pressure to give a syrup $(10 \mathrm{~g})$. The syrup was submitted to a column chromatography on silicic acid $(250 \mathrm{~g})$ and eluted with a mixture of benzene and ethyl acetate $(10: 1, \mathrm{v} / \mathrm{v})$. The fractions that had $R f=0.45$ with the same solvent system gave a syrupy 4,6-O-benzoyl-3-O-benzyl-2deoxy- $\alpha$-D-ribo-hexopyranoside (V) $(1.7 \mathrm{~g}, 12 \%)$, $[\alpha]_{\mathrm{D}}^{20}+137.8^{\circ}\left(c=0.8, \mathrm{CHCl}_{3}\right)$. Anal. Found: C. 70.51 ;
$\mathrm{H}$, 5.91. Calcd. for $\mathrm{C}_{28} \mathrm{H}_{28} \mathrm{O}_{7}$ : C, 70.57, $\mathrm{H}, 5.92$. NMR $\delta_{\mathrm{Me}_{4} \mathrm{Si}_{3}}^{\mathrm{CDCl}_{3}}: 1.80 \sim 2.48\left(2 \mathrm{H}, \mathrm{m}, \mathrm{H}_{2}, \mathrm{H}_{2}{ }^{\prime}\right), 3.40(3 \mathrm{H}$, $\left.\mathrm{s}, \mathrm{OCH}_{3}\right), 4.14\left(1 \mathrm{H}, \mathrm{m}, \mathrm{H}_{3}\right), 4.34 \sim 4.92\left(5 \mathrm{H}, \mathrm{m}, \mathrm{H}_{b}\right.$, $\mathrm{H}_{6}, \mathrm{H}_{8^{\prime}}$, benzyl protons), $5.25\left(1 \mathrm{H}, \mathrm{dd}, J_{3,4}=3 \mathrm{~Hz}\right.$, $\left.J_{4,5}=10 \mathrm{~Hz}, \mathrm{H}_{4}\right)$. The fractions that contained the compound of $R f=0.2$ gave a syrupy VI $(7.0 \mathrm{~g}, 63 \%$, $[\alpha]_{\mathrm{D}}^{21}+117.3^{\circ} \quad\left(c=0.8, \mathrm{CHCl}_{3}\right)$. Anal. Found: $\mathrm{C}$, 67.75; H, 6.37. Calcd. for $\mathrm{C}_{21} \mathrm{H}_{24} \mathrm{O}_{8}: \mathrm{C}, 67.73 ; \mathrm{H}$, $6.50 \% . \quad \mathrm{NMR} \delta_{\mathrm{Me}_{4} \mathrm{Si}}^{\mathrm{CDCl}_{3}}: 1.60 \sim 1.90\left(1 \mathrm{H}, \mathrm{m}, J_{2,2^{\prime}}=\right.$ $\left.15 \mathrm{~Hz}, \mathrm{H}_{2}\right), 2.22 \sim 2.46\left(1 \mathrm{H}, \mathrm{m}, \mathrm{H}_{2^{\prime}}\right), 2.75\left(1 \mathrm{H}, \mathrm{d}, J_{\mathrm{OH}}, \mathrm{H}_{4}\right.$ $=10 \mathrm{~Hz}), 3.34\left(3 \mathrm{H}, \mathrm{s}, \mathrm{OCH}_{3}\right), 3.62\left(1 \mathrm{H}, \mathrm{td}, J_{4, \mathrm{~s}}=\right.$ $\left.3.9 \mathrm{~Hz}, \mathrm{H}_{4}\right), 3.88\left(1 \mathrm{H}, \mathrm{m}, \mathrm{H}_{3}\right), 4.22\left(1 \mathrm{H}, \mathrm{m}, \mathrm{H}_{5}\right), 4.40$ and $4.80(2 \mathrm{H}, 2 \mathrm{~d}, J=12 \mathrm{~Hz}$, benzyl protons), $4.42 \sim$ $4.73\left(2 \mathrm{H}, \mathrm{m}, \mathrm{H}_{\mathrm{B}}, \mathrm{H}_{\mathrm{B}^{\prime}}\right), 5.74\left(1 \mathrm{H}, \mathrm{d}, J=4 \mathrm{~Hz}, \mathrm{H}_{1}\right), 7.20 \sim$ $7.64(8 \mathrm{H}, \mathrm{m}$, aromatic protons), $7.96 \sim 8.13(2 \mathrm{H}, \mathrm{m}$, aromatic protons). IR $\nu_{\max }^{\mathrm{film}} \mathrm{cm}^{-1}: 3500(\mathrm{OH}), 1735$ (CO). 
(E)-Methyl 6-O-benzoyl-4-C-carbomethoxymethylidene-2, 4-dideoxy-a-D-erythro-hexopranoside (VIIa) and (Z)-methyl 6-O-benzoyl-4-C-carbomethoxymethylidene-2, 4-dideoxy- $\alpha$-D-erythro-hexopyranoside (vilib)

A mixture of VI $(3.7 \mathrm{~g}), \mathrm{RuO}_{2}(300 \mathrm{mg})$, saturated $\mathrm{NaHCO}_{3}(10 \mathrm{ml}), \mathrm{NaIO}_{4}(10 \mathrm{~g}), \mathrm{CCl}_{4}(40 \mathrm{ml})$ and water (40 ml) was vigorously stirred for $5 \mathrm{hr}$. Isopropyl alcohol $(10 \mathrm{ml})$ was added to the reaction mixture and the mixture was stirred for additional $15 \mathrm{~min}$. The reaction mixture was diluted with dichloromethane $(100 \mathrm{ml})$ and then filtered with the aid of celite. The filtrate was washed three times with water $(50 \mathrm{ml})$ and then dried over $\mathrm{Mg}_{2} \mathrm{SO}_{4}$. The solvent was evaporated under reduced pressure below $30^{\circ} \mathrm{C}$ and the resulting crude syrupy ketone (VII) (3.3 g) was directly used for the next reaction. To a solution of trimethylphosphonoacetate $(3 \mathrm{~g})$ in dry tetrahydrofurane $(30 \mathrm{ml})$ was added $n$-BuLi $\left(9 \mathrm{ml}\right.$ of $15 \%$ hexane solution) at $-70^{\circ} \mathrm{C}$ under $\mathrm{N}_{2}$ atmosphere. A solution of the crude ketone $(3.3 \mathrm{~g})$ in dry tetrahydrofurane $(15 \mathrm{ml})$ was added dropwise to the ylide solution. The reaction temperature was raised gradually to about $-30^{\circ} \mathrm{C}$ and kept for $2 \mathrm{hr}$ at the temperature and then for $1 \mathrm{hr}$ at $0^{\circ} \mathrm{C}$. After saturated $\mathrm{NH}_{4} \mathrm{Cl}$ solution $(30 \mathrm{ml})$ was added to the reaction mixture, it was extracted five times with ether $(250 \mathrm{ml})$. The ether solution was washed with saturated $\mathrm{NH}_{4} \mathrm{Cl}$ solution $(50 \mathrm{ml})$ and then dried over $\mathrm{Na}_{2} \mathrm{SO}_{4}$. The solvent was removed under reduced pressure to give a syrup $(4 \mathrm{~g})$. The syrup was submitted to a column chromatography on silicic acid $(100 \mathrm{~g})$ and eluted with a mixture of benzene and ethyl acetate $(50: 1, v / v)$. The fractions that contained a compound of $R f=0.5$ (benzene-ethyl acetate, $10: 1, \mathrm{v} / \mathrm{v}$ ) gave a syrupy VIIIa $\left(1.25 \mathrm{~g}, 30 \%\right.$ from VI), $[\alpha]_{\mathrm{D}}^{21}+164.8^{\circ}$ $\left(c=0.2, \mathrm{CHCl}_{8}\right.$ ). Anal. Found: C, 67.55; H, 5.95 . Calcd. for $\mathrm{C}_{24} \mathrm{H}_{28} \mathrm{O}_{7}: \mathrm{C}, 67.59 ; \mathrm{H}, 6.15 \%$. IR $\nu_{\mathrm{max}}^{\text {film }}$ $\mathrm{cm}^{-1}: 1725(\mathrm{CO}), 1665(\mathrm{C}=\mathrm{C}), \quad \mathrm{NMR} \delta_{\mathrm{Me}_{4} \mathrm{Si}_{1}}^{\mathrm{CDCl}}: 1.62$ $\left(1 \mathrm{H}, \mathrm{m}, J_{2,2^{\prime}}=13 \mathrm{~Hz}, \mathrm{H}_{2}\right), 2.76\left(1 \mathrm{H}, \mathrm{m}, \mathrm{H}_{2^{\prime}}\right), 3.34$ $\left(3 \mathrm{H}, \mathrm{s}, \mathrm{OCH}_{3}\right), 3.70\left(3 \mathrm{H}, \mathrm{s}, \mathrm{COOCH}_{3}\right), 4.30 \sim 4.98(3 \mathrm{H}$, $\left.\mathrm{m}, \mathrm{H}_{\mathrm{B}}, \mathrm{H}_{B^{\prime}}\right), 4.44$ and $4.62(2 \mathrm{H}, 2 \mathrm{~d}, J=12 \mathrm{~Hz}$, benzyl protons $), 5.66\left(1 \mathrm{H}, \mathrm{m}, \mathrm{H}_{1}\right), 6.18(1 \mathrm{H}, \mathrm{m}$, vinyl proton), $7.20 \sim 7.71(8 \mathrm{H}, \mathrm{m}$, aromatic protons), $7.94 \sim 8.10$ $(2 \mathrm{H}, \mathrm{m}$, aromatic protons). The fractions that contained a compound of $R f=0.45$ gave a syrupy VIIb $(1.26 \mathrm{~g}, 30 \%),[\alpha]_{\mathrm{D}}^{21}+167.4^{\circ}\left(c=0.8, \mathrm{CHCl}_{3}\right)$. Anal. Found: $\mathrm{C}, 67.55 ; \mathrm{H}$, 5.93. Calcd. for $\mathrm{C}_{24} \mathrm{H}_{28} \mathrm{O}_{7}: \mathrm{C}$, $67.59 ; \mathrm{H}, 6.15 \%$ IR $\nu_{\max }^{\mathrm{fim}} \mathrm{cm}^{-1}: 1725$ (CO), 1665 $(\mathrm{C}=\mathrm{C}) . \quad \mathrm{NMR} \delta_{\mathrm{Me}_{4} \mathrm{Si}^{3}}^{\mathrm{CDCl}}: 1.88 \sim 2.42\left(2 \mathrm{H}, \mathrm{m}, J_{2,2^{\prime}}=\right.$ $\left.14 \mathrm{~Hz}, \mathrm{H}_{2}, \mathrm{H}_{2^{\prime}}\right), 3.43\left(3 \mathrm{H}, \mathrm{s}, \mathrm{OCH}_{3}\right), 3.64(3 \mathrm{H}, \mathrm{s}$, $\left.\mathrm{COOCH}_{3}\right), 4.44 \sim 4.63\left(4 \mathrm{H}, \mathrm{m}, \mathrm{H}_{5}, \mathrm{H}_{5^{\prime}}\right.$, benzylprotons), $4.82\left(1 \mathrm{H}, \mathrm{d}, J=4 \mathrm{~Hz}, \mathrm{H}_{3}\right), 5.14\left(1 \mathrm{H}, \mathrm{m}, \mathrm{H}_{3}\right), 5.50(1 \mathrm{H}$, $\mathrm{t}, J=4 \mathrm{~Hz}), 5.88(1 \mathrm{H}, \mathrm{s}$, vinyl proton $), 7.16 \sim 7.60(8 \mathrm{H}$, $\mathrm{m}$, aromatic protons), $7.96 \sim 8.15(1 \mathrm{H}, \mathrm{m}$, aromatic protons).
Methyl 6-O-benzoyl-4-C-carboxymethylene-2, 4-dideoxy$\alpha-D$-ribo-hexopyranoside $2^{\prime} \rightarrow 3$ lactone $(\mathrm{X})$

A mixture of VIIIa $(1 \mathrm{~g})$ and $10 \% \mathrm{Pd}-\mathrm{C}(1 \mathrm{~g})$ in ethanol $(100 \mathrm{ml})$ was shaken under $\mathrm{H}_{2}$ atmosphere for $2 \mathrm{hr}$ at room temperature. After the catalyst was filtered off, the solvent was evaporated under reduced pressure to give a syrup ( $1 \mathrm{~g})$. The syrup was dissolved in toluene $(50 \mathrm{ml})$ and silicic acid $(5 \mathrm{~g})$ was added to the solution. The mixture was refluxed gently for $5 \mathrm{hr}$ and then cooled to room temperature. The silicic acid was filtered off and the filtrate was evaporated under reduced pressure to give a crystalline mass. It was recystallized from a mixture of hexane and ether to give X $(590 \mathrm{mg}, 83 \%), \operatorname{mp~} 102 \sim 103^{\circ} \mathrm{C},[\alpha]_{\mathrm{D}}^{21}+65.0^{\circ}(c=$ $0.2, \mathrm{CHCl}_{3}$ ). Anal. Found: $\mathrm{C}, 62.63 ; \mathrm{H}, 5.73$. Calcd. for $\mathrm{C}_{10} \mathrm{H}_{18} \mathrm{O}_{8}: \mathrm{C}, 62.74 ; \mathrm{H}, 5.92 \%$. IR $\nu_{\max }^{\mathrm{KBt}} \mathrm{cm}^{-1}$ : $1760(\mathrm{CO}), 1710(\mathrm{CO}) . \quad \mathrm{NMR} \delta_{\mathrm{M}_{4} \mathrm{Si}_{1}}^{\mathrm{CDOl}}: 2.10 \sim 2.80(5 \mathrm{H}$, $\left.\mathrm{m}, \mathrm{H}_{2}, \mathrm{H}_{2}, \mathrm{H}_{4}, \mathrm{CH}_{2} \mathrm{CO}\right), 3.34\left(3 \mathrm{H}, \mathrm{s}, \mathrm{OCH}_{3}\right), 4.01$ $\left(1 \mathrm{H}, \mathrm{m}, \mathrm{H}_{5}\right), 4.44\left(2 \mathrm{H}, \mathrm{m}, \mathrm{H}_{\theta}, \mathrm{H}_{6}{ }^{\prime}\right), 4.68\left(1 \mathrm{H}, \mathrm{m}, \mathrm{H}_{3}\right)$, $4.86(1 \mathrm{H}, \mathrm{t}, J=4 \mathrm{~Hz}), 7.34 \sim 7.68(3 \mathrm{H}, \mathrm{m}$, aromatic protons), $8.00 \sim 8.09(2 \mathrm{H}, \mathrm{m}$, aromatic protons).

\section{Methyl 6-O-benzoyl-4-C-carbomethoxymethylene-2, 4-dideoxy- $\alpha-D-x y$ lo-hexopyranoside (XI)}

A mixture of VIIb $(1 \mathrm{~g})$ and $10 \% \mathrm{Pd}-\mathrm{C}(1 \mathrm{~g})$ in ethanol $(100 \mathrm{ml})$ was shaken under $\mathbf{H}_{2}$ atmosphere for $2 \mathrm{hr}$ at room temperature. The catalyst was filtered off and the filtrate was evaporated under reduced pressure to give a syrup $(1 \mathrm{~g})$. The syrup was dissolved in toluene $(100 \mathrm{ml})$ and the solution was gently refluxed
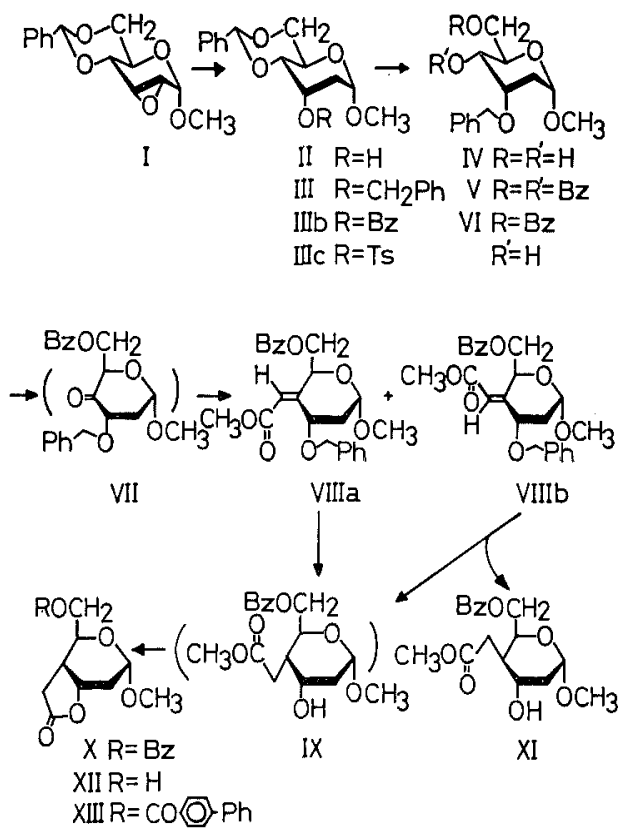

FIG. 4. 
in the presence of silicic acid $(5 \mathrm{~g})$ for $5 \mathrm{hr}$. After the silicic acid was filtered off, the filtrate was evaporated under reduced pressure to give a syrup $(1 \mathrm{~g})$. The syrup was submitted to a column chromatography on silicic acid $(100 \mathrm{~g})$ and eluted with a mixture of hexane and ether $(3: 1, v / v)$. The fractions that contained a compound with $R f=0.15$ (hexane: ehter $=3: 1, \mathrm{v} / \mathrm{v}$ ) gave crystalline XI $\left(320 \mathrm{mg}, 40 \%\right.$ ) mp $77 \sim 78^{\circ} \mathrm{C}$, $[\alpha]_{D}^{22}+97.2^{\circ}\left(c=0.1, \mathrm{CHCl}_{3}\right)$. Anal. Found: $\mathrm{C}, 60.23$; $\mathrm{H}, 6.47$. Calcd. for $\mathrm{C}_{17} \mathrm{H}_{22} \mathrm{O}_{7}: \mathrm{C}, 60.34 ; \mathrm{H}, 6.55 \%$. $\mathrm{IR} \nu_{\mathrm{m} \mathrm{ax}}^{\mathrm{K} \mathrm{Rr}} \mathrm{cm}^{-1}: 3550(\mathrm{OH}), 1735$ and $1710(\mathrm{CO})$. NMR $\delta_{\mathrm{Me}_{4} \mathrm{Si}_{\mathrm{S}}}^{\mathrm{CDO}}: 1.82 \sim 2.78\left(5 \mathrm{H}, \mathrm{m}, \mathrm{H}_{2}, \mathrm{H}_{2^{\prime}}, \mathrm{H}_{4}, \mathrm{CH}_{2} \mathrm{CO}\right)$, $3.37\left(3 \mathrm{H}, \mathrm{s}, \mathrm{OCH}_{3}\right), 3.63\left(3 \mathrm{H}, \mathrm{s}, \mathrm{COOCH}_{3}\right), 3.86(1 \mathrm{H}$, $\left.\mathrm{m}, \mathrm{H}_{3}\right), 4.37\left(2 \mathrm{H}, \mathrm{m}, \mathrm{H}_{8}, \mathrm{H}_{\mathrm{B}^{\prime}}\right), 4.60\left(1 \mathrm{H}, \mathrm{m}, \mathrm{H}_{5}\right), 4.75$ $\left(1 \mathrm{H}, \mathrm{m}, \mathrm{H}_{2}\right), 7.32 \sim 7.70(3 \mathrm{H}, \mathrm{m}$, aromatic protons), $7.96 \sim 8.14(2 \mathrm{H}, \mathrm{m}$, aromatic protons). The fractions that contained a compound with $R f=0.08$ gave $\mathrm{X}$ (320 mg, $40 \%$ ).

Methyl 4-C-carboxymethylene-2, 4-dideoxy-a-D-ribohexopyranoside $2^{\prime} \rightarrow 3$ lactone (XII)

A solution of $\mathrm{X}(1 \mathrm{~g})$ in $0.05 \mathrm{~N}$ methanolic sodium methoxide $(100 \mathrm{ml})$ was stirred overnight at room temperature. Acetic acid $(5 \mathrm{ml})$ was added to the reaction mixture and the solvent was removed under reduced pressure to give a syrup $(1 \mathrm{~g})$. The syrup was purified by column chromatography on silicic acid $(50 \mathrm{~g})$ using a mixture of $\mathrm{CHCl}_{3}$ and $\mathrm{MeOH}(20: 1, \mathrm{v} / \mathrm{v})$ as an eluent to give a syrupy XII (550 mg, $83 \%),[\alpha]_{D}^{21}+100^{\circ}$ $\left(c=0.09, \mathrm{CHCl}_{3}\right)$. Anal. Found: $\mathrm{C}, 53.18 ; \mathrm{H}, 6.98$. Calcd. for $\mathrm{C}_{8} \mathrm{H}_{14} \mathrm{O}_{5}: C, 53.46 ; \mathrm{H}, 6.89 \%$. IR $\nu_{\max }^{\mathrm{fllm}}$ $\mathrm{cm}^{-1}: 3500(\mathrm{OH}), 1760(\mathrm{CO}) . \quad \mathrm{NMR} \delta_{\mathrm{Me}_{4} \mathrm{Si}}^{\mathrm{CDCl}}: 1.92 \sim$ $2.86\left(6 \mathrm{H}, \mathrm{m}, \mathrm{OH}, \mathrm{H}_{2}, \mathrm{H}_{2^{\prime}}, \mathrm{H}_{4}, \mathrm{CH}_{2} \mathrm{CO}\right), 3.34(3 \mathrm{H}, \mathrm{s}$, $\left.\mathrm{OCH}_{3}\right), 3.50 \sim 3.90\left(3 \mathrm{H}, \mathrm{m}, \mathrm{H}_{5}, \mathrm{H}_{6}, \mathrm{H}_{6^{\prime}}\right), 4.66(1 \mathrm{H}$, $\left.\mathrm{m}, \mathrm{H}_{3}\right), 4.85\left(1 \mathrm{H}, \mathrm{m}, \mathrm{H}_{1}\right)$.

\section{6-O-p-Phenylbenzoyl-4-C-carboxymethylene-2, 4- dideoxy-a-D-ribo-hexopyranoside (XIII)}

To a solution of XII $(500 \mathrm{mg})$ in pyridine $(5 \mathrm{ml})$ was added $p$-phenylbenzoyl chloride $(1.5 \mathrm{~g})$ at $0^{\circ} \mathrm{C}$. The mixture was stirred overnight at room temperature and then powered into a cold saturated $\mathrm{NaHCO}_{3}$ solution $(10 \mathrm{ml})$. The mixture was extracted three times with dichloromethane $(50 \mathrm{ml})$. The organic layer was successively washed with cold $3 \% \mathrm{H}_{2} \mathrm{SO}_{4}$ $(50 \mathrm{ml})$, water $(10 \mathrm{ml})$, saturated $\mathrm{NaHCO}_{3}(10 \mathrm{ml})$ and then water $(10 \mathrm{ml})$. The dichloromethane solution was dried over $\mathrm{Na}_{2} \mathrm{SO}_{4}$ and evaporated under reduced pressure to give a crystalline XIII $(880 \mathrm{mg}, 93 \%)$. It was recrystallized from $\mathrm{MeOH}, \mathrm{mp} 149 \sim 150^{\circ} \mathrm{C}$, $[\alpha]_{\mathrm{D}}^{20}+48.6^{\circ} \quad\left(c=0.18, \mathrm{CHCl}_{3}\right)$. Anal. Found: 69.06; $\mathrm{H}, 5.50$. Calcd. for $\mathrm{C}_{22} \mathrm{H}_{22} \mathrm{O}_{6}: \mathrm{C}, 69.10 ; \mathrm{H}, 5.80 \%$. IR $\nu_{\max }^{\mathrm{KBr}} \mathrm{cm}^{-1}: 1760$ and $1710(\mathrm{CO})$. NMR $\delta_{\mathrm{Me}_{4} \mathrm{Si}}^{\mathrm{CDCl}}$ : $2.08 \sim 2.84\left(5 \mathrm{H}, \mathrm{m}, \mathrm{H}_{2}, \mathrm{H}_{2^{\prime}}, \mathrm{H}_{4}, \mathrm{CH}_{2} \mathrm{CO}\right), 3.36(3 \mathrm{H}, \mathrm{s}$, $\left.\mathrm{OCH}_{3}\right), 4.02\left(1 \mathrm{H}, \mathrm{m}, \mathrm{H}_{5}\right), 4.40 \sim 4.52\left(2 \mathrm{H}, \mathrm{m}, \mathrm{H}_{8}, \mathrm{H}_{6^{\prime}}\right)$, $4.69\left(1 \mathrm{H}, \mathrm{m}, \mathrm{H}_{3}\right), 4.87(1 \mathrm{H}, \mathrm{t}, J=4 \mathrm{~Hz}), 7.32 \sim 7.76$ ( $8 \mathrm{H}, \mathrm{m}$, aromatic protons), $8.04 \sim 8.18(2 \mathrm{H}, \mathrm{m}$, aromatic protons).

Acknowledgement. The authors wish to express their thanks to Dr. H. Homma and his collaborators for elemental analyses and Mr. J. Uzawa and Mrs. T. Chigimatsu for measurement of NMR spectra.

\section{REFERENCES}

1) M. Hamberg and B. Samuelsson, Proc. Natl. Acad. Sci. U.S.A., 71, 3400 (1974).

2) M. Hamberg, J. Svensson and B. Samuelsson, ibid., 72, 2994 (1975).

3) (a) (+)-Oxybiotin: H. Ohrui, H. Kuzuhara and $\mathbf{S}$. Emoto, Agric. Biol. Chem., 35, 752 (1971) (b) $(+)$-Dethiobiotin: H. Kuzuhara, H. Ohrui and S. Emoto, ibid., 35, 8 (1971) (c) (+)-Biotin: H. Ohrui and S. Emoto, Tetrahedron Lett., 32, 2765 (1975) (d) (+)- and (-)-Avenaciolide: $\mathbf{H}$. Ohrui and S. Emoto, ibid, 42, 3667 (1975) (e) (S)(-)-Frontalin: H. Ohrui and S. Emoto, Agric. Biol. Chem., 40, 2267 (1976).

4) N. A. Nelson and R. W. Jackson, Tetrahedron Lett., 37, 3275 (1976).

5) R. C. Kelly, I. Schletter and S. J. Stein, ibid., 37, 3279 (1976).

6) After we have finished this work, a brief comunication about the synthesis of optically active Thromboxane $B_{2}$ from $D$-glucose was reported by S. Hanessian and P. Lavallee in Can. J. Chem., 55, 562 (1977).

7) R. L. Whistler and M. L. Wolfrom, Methods Carbohydr. Chem., 1, 107 (1962).

8) D. A. Prins, J. Am. Chem. Soc., 70, 3955 (1948).

9) Judging from the identity of the melting points of the two compounds, the lactone prepared by the Upjohn Company group would be optically active. However, the data concerning the optical rotation and the absolute configuration of the compound have not been reported by them. 